Abstracta Iranica

Revue bibliographique pour le domaine irano-aryen

Volume 42-43 | 2021

Comptes rendus des publications de 2019-2020

\title{
Omid Azadibougar. World Literature and Hedayat's Poetics of Modernity
}

\section{Laetitia Nanquette}

\section{(2) OpenEdition}

1 Journals

\section{Electronic version}

URL: https://journals.openedition.org/abstractairanica/52748

DOI: 10.4000/abstractairanica. 52748

ISSN: 1961-960X

Publisher:

CNRS (UMR 7528 Mondes iraniens et indiens), Éditions de l'IFRI

\section{Electronic reference}

Laetitia Nanquette, "Omid Azadibougar. World Literature and Hedayat's Poetics of Modernity", Abstracta Iranica [Online], Volume 42-43 | 2021, document 1, Online since 15 April 2021, connection on 14 December 2022. URL: http://journals.openedition.org/abstractairanica/52748 ; DOI: https://doi.org/ 10.4000/abstractairanica.52748

This text was automatically generated on 14 December 2022.

All rights reserved 


\title{
Omid Azadibougar. World Literature and Hedayat's Poetics of Modernity
}

\author{
Laetitia Nanquette
}

\section{REFERENCES}

Omid Azadibougar. World Literature and Hedayat's Poetics of Modernity. London/New York: Palgrave Macmillan, 2020, p.XVII-203, 5 b/w \& 7 in colour illust., DOI:

10.1007/978-981-15-1691-7

1 This book stems from the author's exploration of the encounter between Iran and modernity. This preoccupation takes shape here through the examination of Sadegh Hedayat's texts in their variety and complexity. Azadibougar analyses Hedayat's poetics of modernity and his response to his own peripheral condition in world literature.

2 The book takes a strong stance against the tragic-romantic approach and the focus on Hedayat's life of many scholarly texts that studied this influential author.

3 It is both a great introduction to a canonical writer, critical to understand the directions taken by Persian literature in the $20^{\text {th }}$ century, and a convincing reflection on the connections between Hedayat's writings and his plural interests in folklore, as well as translation from both ancient languages like Pahlavi and modern ones like French. It represents an innovative and exciting approach to modern Persian literature. 


\section{AUTHORS}

\section{LAETITIA NANQUETTE}

University of New South Wales, Sydney 